\title{
Mouse housing system using pressurized cages intraventilated: Reproductive performance and lung histopathology
}

\author{
Alexandre Martinewski, Caio S. C. Correia, Nivea L. de Souza, José L. B. Merusse \\ Department of Pathology, School of Veterinary Medicine, University of São Paulo, São Paulo, Brazil; martinewski@gmail.com
}

Received 25 March 2013; revised 23 May 2013; accepted 5 June 2013

Copyright (C) 2013 Alexandre Martinewski et al. This is an open access article distributed under the Creative Commons Attribution License, which permits unrestricted use, distribution, and reproduction in any medium, provided the original work is properly cited.

\begin{abstract}
The present study is a report on the use of individual micro fans attached to the lids of mice cages, leading to cage pressurization and internal ventilation. The effect of this ventilation system was analyzed in relation to reproductive performance and lung histopathology of $B A L B / c$, SPF mice, and was based on the results of previous studies, which demonstrated the mechanical efficiency of the system. No statistical differences were observed in relation to interbirth interval, number of offspring born, and number and weight of offspring weaned. Lung histopathology, however, showed that the group of animals kept under the microenvironmental ventilation system for 229 days presented no pulmonary lesions (score 0 ), whereas animals in the control group, kept in a conventional micro isolator, without ventilation, presented score 1 (discrete inflammatory reaction and hemorrhage, 5 animals); score 2 (hemorrhage, 1 animal) and score 3 (interstitial pneumonia and hemorrhage or peribronchitis and hemorrhage, 2 animals). Data demonstrates that the presence and functioning of the micro fans on the lids did not interfere with the reproductive performance of the animals and improve the quality in laboratory animals production, providing them without any kind of pulmonary lesions.
\end{abstract}

Keywords: Component; Formatting; Style; Styling; Insert

\section{INTRODUCTION}

Several studies [1-6] have demonstrated the efficiency of microenvironmental ventilation systems (MV) [7] for laboratory animals, these systems are more efficient than General Diluting Ventilation (GDV) ones, which were previously recommended for this purpose [8-12]. The environmental and sanitary parameters affect directly the reproduction efficiency in mice. [13]

Progresses in intracage environment [14-17] have been required to reach comfort and quality for laboratory animals recently. Microenvironmental atmospheric control systems $[18,19]$ have demonstrated improved sanitary status in animals experimentally bred and maintained under such ventilation systems [20], particularly when intraventilated and pressurized cages of recent design are used [16,17], providing low concentrations of ammonia, moisture [21] and carbon dioxide [22].

The use of individual micro fans attached to the lid of the cages (pressurized intraventilated-PIV), has recently been introduced showing a low cost solution and smaller ammonia concentrations in cages microenvironment $[23,24]$. This alternative is based on the use of direct-current micro fans for ventilating and pressurizing these compartments. Previous experiments demonstrated that micro fans similar to those employed as conventional desktop computers cooling fans are suitably adaptable to voltage fluctuations, allowing for precise airflow control. In addition to their low implementation costs, micro fans are easily available on the market, require little or almost no maintenance, and have an expected mean lifespan of 20,000 hours under constant operation. The purpose of this study was to design and test a technical alternative to PIV-type microenvironmental systems, using direct-current micro fans instead which can be used with thermoelectric technology [19]. Based on results and improvements obtained using PIV, the objective of the present trial was to assess the reproductive performance and to quantify pulmonary lesions observed in mice kept under a microenvironmental ventilation system using micro fans. 


\section{MATERIALS AND METHOD}

\subsection{Animals and Group Formation}

Forty four Specific Pathogen Free (SPF) BALB/c mice weighting about 15 grams and 21 days of age were used, separated in male-female pairs: 16 experimental pairs, kept in PIV cages, and 6 control pairs, kept in regular filter-top (FT) cages. All cages used are made of the same material - polypropylene, and have the same size$28 \times 17 \times 12 \mathrm{~cm}\left(5712 \mathrm{~cm}^{3}\right)$. Both groups were housed in a standard holding room for laboratory animals equipped with a conventional atmospheric control system under GDV.

\subsection{Husbandry}

The animals were housed and assayed under conditions of controlled temperature $\left(22^{\circ} \mathrm{C} \pm 2^{\circ} \mathrm{C}\right)$, humidity (45\% - 65\%) and artificial light (12-h light/12-h dark, lights on at 7:00 a.m.) with free access to rodent chow (Nuvilab CR-1 Autoclavavel $^{\circledR}$, Nuvital, Colombo , PR) and water (autoclaved and acidified, approximately $\mathrm{pH}$ 4.0). Bedding (Pinus sp. 20-mm shavings, autoclaved) and cages were autoclaved and changed weekly, for both groups. Control cages (FT)-standard polypropylene FT cages-had the same amount of food, water, and bedding as did experimental cages (PIV). The room was ventilated at approximately $22 \mathrm{ACH}$ and PIV cages at 173 ACH. PIV system consists in a regular microfan attached to the top of the cage filter holder which is responsible to provide airflow inside the cage [24].

Animals were housed, used and euthanized in accordance to the guidelines of the Committee on Care and Use of Laboratory Animal Resources of the School of Veterinary Medicine, University of São Paulo; these guidelines are similar to those of the National Research Council, USA [25].

\subsection{Experimental Design}

The reproductive performance trial lasted for 180 days. After mating both FT and PIV pairs, the following parameters were evaluated for both groups: interbirth interval (in days); number of offspring born in each parturition; number of offspring weaned in each parturition; weight of the offspring after weaning. For comparative histopathology of the lungs of mice from both groups 16 animals were chosen randomly. Eight of them were kept under the PIV system and other eight of them under the FT system. These two groups were the first generation of animals housed from birth to the last experimental day in each of the systems. At the end of a 229-day period, animals were euthanized in a $\mathrm{CO}_{2}$ chamber and necropsy was performed. The intact lungs were perfused with 0.8 $\mathrm{ml}$ of Bouin solution and immediately transferred to flasks containing the same solution, where they remained for 48 hours. After this period of time, one fragment, located at the same position in each of the four lung lobules was collected and submitted to histopathological techniques for fixation and inclusion, and were stained by Hematoxylin-Eosin (HE). All fields of the slides produced were analyzed.

\subsection{Statistical Analysis}

The statistical analysis was performed using the software package SPSS SYSTAT ${ }^{\circledR}$ Version 17.0. The data were analyzed unpaired Student's t test and MannWhitney test. The probability of $p<0.05$ was considered to show significant differences for all comparisons made. Data are presented as mean \pm standard deviation.

\section{RESULTS}

No statistical differences were observed in interbirth interval (Table 1). The period corresponds to the average in days, for both groups.

Table 2 shows the number of offspring born. Comparing PIV and FT groups, there is no statistical difference observed.

Table 3 shows the number of offspring weaned. There were not found statistical differences between experimental (PIV) and control (FT) groups.

Weight of the animals after weaning is shown in Table 4. No significant differences were observed either in the comparison between the groups or between the intervals studied.

Lesions were described and evaluated according to a rating score ranging from 0 to 3 (Table 5).

Due to the fact that the animals were killed in a $\mathrm{CO}_{2}$ chamber - the standard procedure, considered to be a more ethical and humanitarian method - a certain degree of pulmonary congestion could be expected in the histopathological analysis of the lung of all the animals. In fact, this was observed in all the samples, and this parameter was not considered in the histopathological analysis.

Table 6 shows the score of the lesions in the experimental (PIV) and control (FT) groups.

Table 7 shows the statistical comparison between the experimental (PIV) and control (FT) groups.

The analysis of the results showed absence of lesions in all the animals in the PIV group (Figure 1). On the other

Table 1. Score and type of lesion observed in histopathological analysis of mice kept under the PIV and FT systems.

\begin{tabular}{cc}
\hline Score & Meaning \\
\hline 0 & Absence of lesion \\
1 & Discrete inflammatory reaction and discrete hemorrhage \\
2 & Hemorrhage \\
3 & Interstitial pneumonia and hemorhage \\
& or peribronchitis and hemorrhage \\
\hline
\end{tabular}


hand, animals of the FT group presented different lesions.

Figure 2 shows interstitial pneumonia and hemorrhage (1 case, score 3 ).

Figure 3 shows peribronchitis and hemorrhage (1 case, score 3 ).

Figure 4 shows hemorrhage ( 1 case, score 2 ).

Figure 5 shows discrete inflammatory reaction and discrete hemorrhage ( 5 cases, score 1 ).

\section{DISCUSSION}

Comparison between the data on reproductive performance of the groups did not present statistically significant differences. Although a tendency for a smaller interbirth interval in the PIV groups could be observed (Table 1), it was not considered to be a statistically different. Number of offspring born (Table 2), and number and weight of offspring weaned (Table 3), were also similar for both groups. These data support that the PIV system implementation would not alter the productivity of mice colonies kept in the same conditions described in this paper. If the hypothesis of a smaller interbirth interval were confirmed, there would also be an increase in productivity.

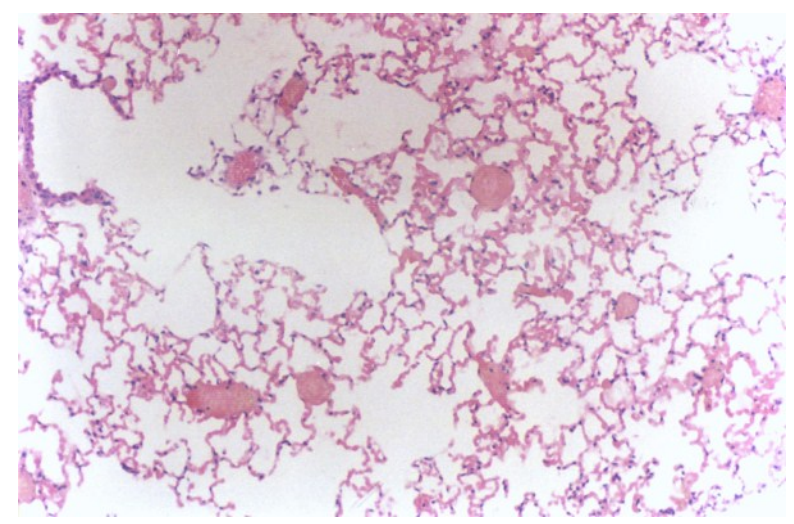

Figure 1. Histological lung section representative of animals in the PIV group.

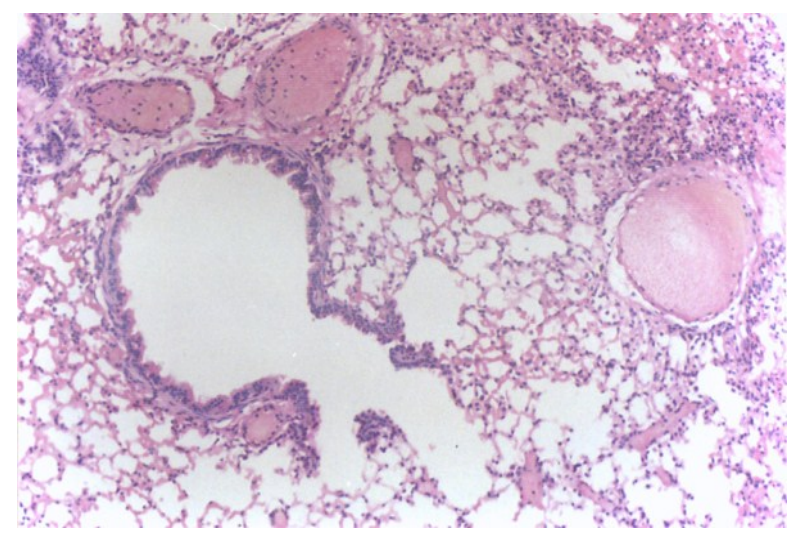

Figure 2. Histological lung section of FT group. Interstitial pneumonia and hemorrhage may be observed.

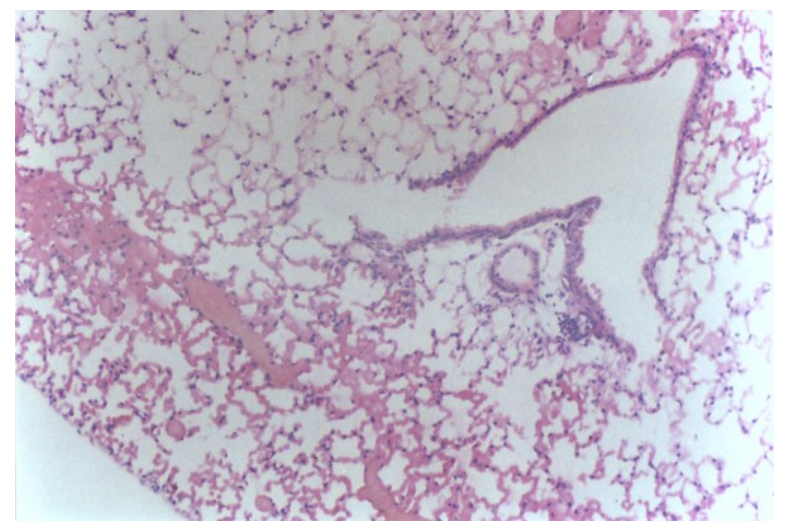

Figure 3. Histological lung section of FT group. Peribronchitis and hemorrhage may be observed.

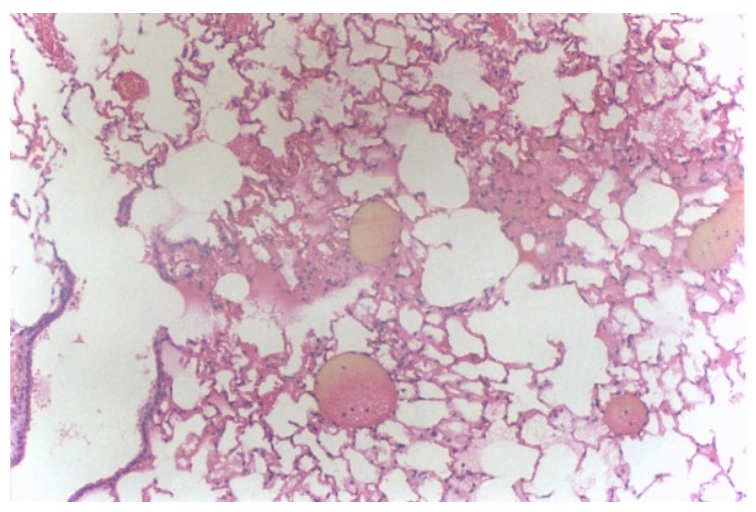

Figure 4. Histological lung section of FT group. Hemorrhage may be observed.

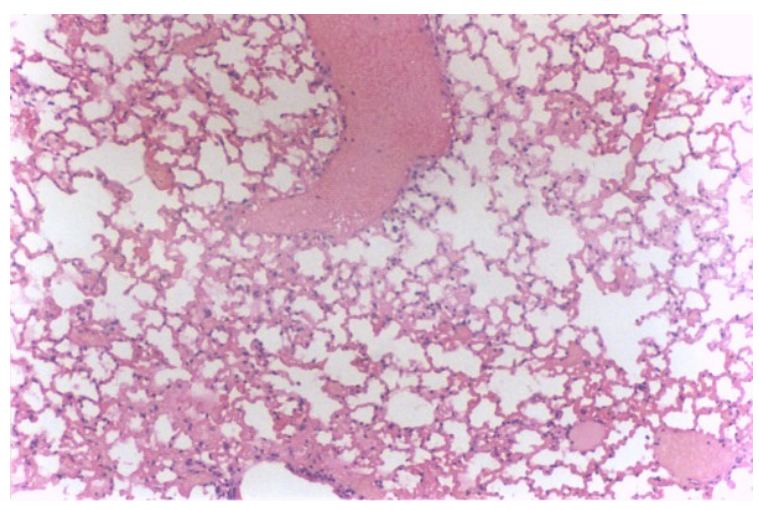

Figure 5. Histological lung section of FT group. Discrete inflammatory reaction and hemorrhage may be observed.

On the other hand, although the reproductive performance was not different for both groups, the PIV system produced an improvement in the sanitary status of the animals. Results of the histopathological analysis (Tables 6 and 7) clearly indicate the absence of either low or high intensity lesions in PIV animals. Those kept in the FT system, however, presented both low and high intensity lesions. The long period in which animals were kept in the system should be emphasized here, 229 days 
Table 2. Interbirth interval (mean \pm standard deviation, in days) of mice mated and kept in PIV and FT systems.

\begin{tabular}{|c|c|c|c|c|c|}
\hline Group/parturition & Mating to $1 \mathrm{st}$ & 1 st to 2 nd & 2 nd to 3 rd & 3 rd to 4 th & 4 th to 5 th \\
\hline PIV & $\begin{array}{c}26.90 \pm 4.70 \\
n=10 / 10\end{array}$ & $\begin{array}{c}31.60 \pm 12.23 \\
n=10 / 10\end{array}$ & $\begin{array}{c}37.40 \pm 15.87 \\
n=10 / 10\end{array}$ & $\begin{array}{c}41.50 \pm 14.10 \\
n=10 / 10\end{array}$ & $\begin{array}{c}35.40 \pm 11.66 \\
n=10 / 10\end{array}$ \\
\hline FT & $\begin{array}{c}33.83 \pm 12.53 \\
n=6 / 6\end{array}$ & $\begin{array}{c}39.80 \pm 11.10 \\
n=5 / 6\end{array}$ & $\begin{array}{c}44.40 \pm 5.37 \\
n=5 / 6\end{array}$ & $\begin{array}{c}37.20 \pm 9.18 \\
n=5 / 6\end{array}$ & $\begin{array}{c}33.60 \pm 9.21 \\
n=5 / 6\end{array}$ \\
\hline
\end{tabular}

Note: $\mathrm{n}=$ number of females that gave birth/total number of females in the group. $\mathrm{p}<0.05$ Student's $\mathrm{t}$ test.

Table 3. Number of mice born under PIV and FT systems (mean \pm standard deviation).

\begin{tabular}{|c|c|c|c|c|c|}
\hline Group & 1st parturition & 2nd parturition & 3rd parturition & 4th parturition & 5 th parturition \\
\hline PIV & $\begin{array}{c}4.50 \pm 1.58 \\
n=10 / 10\end{array}$ & $\begin{array}{c}4.90 \pm 2.33 \\
n=10 / 10\end{array}$ & $\begin{array}{c}5.50 \pm 2.63 \\
n=10 / 10\end{array}$ & $\begin{array}{c}5.40 \pm 1.58 \\
n=10 / 10\end{array}$ & $\begin{array}{c}5.70 \pm 1.95 \\
n=10 / 10\end{array}$ \\
\hline FT & $\begin{array}{c}4.00 \pm 1.90 \\
n=6 / 6\end{array}$ & $\begin{array}{c}6.40 \pm 0.55 \\
n=5 / 6\end{array}$ & $\begin{array}{c}4.60 \pm 1.82 \\
n=5 / 6\end{array}$ & $\begin{array}{c}4.20 \pm 3.11 \\
n=5 / 6\end{array}$ & $\begin{array}{c}7.20 \pm 2.39 \\
n=5 / 6\end{array}$ \\
\hline
\end{tabular}

Note: $\mathrm{n}=$ number of females that gave birth/total number of females in the group. $\mathrm{p}<0.05$ Student's $\mathrm{t}$ test.

Table 4. Number of mice weaned under PIV and FT systems (mean \pm standard deviation).

\begin{tabular}{|c|c|c|c|c|c|}
\hline Group & 1st parturition & 2nd parturition & 3rd parturition & 4th parturition & 5th parturition \\
\hline PIV & $\begin{array}{c}4.50 \pm 1.58 \\
n=10 / 10\end{array}$ & $\begin{array}{c}4.80 \pm 2.15 \\
n=10 / 10\end{array}$ & $\begin{array}{c}5.30 \pm 2.31 \\
n=10 / 10\end{array}$ & $\begin{array}{c}5.40 \pm 1.58 \\
n=10 / 10\end{array}$ & $\begin{array}{c}5.60 \pm 1.78 \\
n=10 / 10\end{array}$ \\
\hline FT & $\begin{array}{c}4.0 \pm 1.90 \\
n=6 / 6\end{array}$ & $\begin{array}{c}6.20 \pm 0.84 \\
n=5 / 6\end{array}$ & $\begin{array}{c}4.20 \pm 1.64 \\
n=5 / 6\end{array}$ & $\begin{array}{c}4.00 \pm 3.39 \\
n=5 / 6\end{array}$ & $\begin{array}{c}7.20 \pm 2.39 \\
n=5 / 6\end{array}$ \\
\hline
\end{tabular}

Note: $\mathrm{n}=$ number of females that gave birth/total number of females in the group. $\mathrm{p}<0.05$ Student's $\mathrm{t}$ test.

Table 5. Post-weaning weight of mice kept under PIV and FT systems (mean \pm standard deviation).

\begin{tabular}{|c|c|c|c|c|c|c|c|}
\hline \multicolumn{8}{|c|}{ Days } \\
\hline Group & 28 & 35 & 42 & 49 & 56 & 63 & 70 \\
\hline PIV & $\begin{array}{c}10.25 \pm 0.88 \\
n=20\end{array}$ & $\begin{array}{c}15.925 \pm 1.48 \\
n=20\end{array}$ & $\begin{array}{c}19.95 \pm 1.74 \\
n=20\end{array}$ & $\begin{array}{c}21.375 \pm 1.63 \\
n=20\end{array}$ & $\begin{array}{c}21.775 \pm 1.76 \\
n=20\end{array}$ & $\begin{array}{c}22.575 \pm 2.03 \\
n=20\end{array}$ & $\begin{array}{c}23.275 \pm 2.15 \\
n=20\end{array}$ \\
\hline FT & $\begin{array}{c}10.21 \pm 1.02 \\
n=19\end{array}$ & $\begin{array}{c}15.97 \pm 1.89 \\
n=19\end{array}$ & $\begin{array}{c}20.02 \pm 1.94 \\
n=19\end{array}$ & $\begin{array}{c}20.55 \pm 1.85 \\
n=19\end{array}$ & $\begin{array}{c}21.1 \pm 2.21 \\
\mathrm{n}=19\end{array}$ & $\begin{array}{c}22.05 \pm 2.32 \\
n=19\end{array}$ & $\begin{array}{c}22.76 \pm 2.2 \\
\mathrm{n}=19\end{array}$ \\
\hline
\end{tabular}

Note: $\mathrm{p}<0.05$ Student's $\mathrm{t}$ test.

Table 6. Classification of the lesions in the experimental (PIV) and control (FT) groups-Score of the lesions observed.

\begin{tabular}{ccc}
\hline Group/animal & Lesion & Score \\
\hline PIV/1 & Not observed & 0 \\
PIV/2 & Not observed & 0 \\
PIV/3 & Not observed & 0 \\
PIV/4 & Not observed & 0 \\
PIV/5 & Not observed & 0 \\
PIV/6 & Not observed & 0 \\
PIV/7 & Not observed & 0 \\
PIV/8 & Not observed & 3 \\
FT/1 & Interstitial pneumonia and hemorrhage & 2 \\
FT/2 & Hemorrhage & 3 \\
FT/3 & Peribronchitis and hemorrhage & 1 \\
FT/4 & Discrete inflammatory reaction and discrete hemorrhage & 1 \\
FT/5 & Discrete inflammatory reaction and discrete hemorrhage & 1 \\
FT/6 & Discrete inflammatory reaction and discrete hemorrhage & 1 \\
FT/7 & Discrete inflammatory reaction and discrete hemorrhage & 1 \\
FT/8 & Discrete inflammatory reaction and discrete hemorrhage & \\
\hline
\end{tabular}


Table 7. Statistical comparison between lesion intensities in the lungs of animals from PIV and groups.

\begin{tabular}{lcc}
\hline Groups & PIV & FT \\
\hline Mean \pm standard deviation of the scores & $0.1^{*} \pm 7.244 \times 10^{-21}$ & $1.725 \pm 0.9161^{* *}$ \\
\hline $\begin{array}{l}\text { Because it is not possible to use values equal to zero in the statistical analysis, } 0.1 \text { was added to all the scores of all the groups. }{ }^{* *} \text { Statistically significant differ- } \\
\text { ence. } p<0.05 \text { Mann-Whitney's test. }\end{array}$
\end{tabular}

(around 7.5 months). Considering the fact that these were experimental animals, this period was long enough for the PIV system to produce any lung alterations, which were not observed, though. The fact that all the animals were born in the respective systems in which they were observed make it impossible to blame the housing in any other system for the lesions observed in the FT animals.

Up to present experimental stage with the PIV system using continuous flow micro fans, the following aspects were be observed: high reliability, low cost, non-interference with the reproductive performance of the animals and improvement of their sanitary status. Therefore, the system would contribute for the production of higher quality animals, enabling the reduction of the quantity of animals used in certain research trials.

\section{ACKNOWLEDGEMENTS}

The study reported in this paper was developed as part of the Master's dissertation submitted by the first author to the Graduate Program in Experimental and Compared Pathology, Department of Pathology, School of Veterinary Medicine and Animal Science, University of São Paulo. Financial support was provided by Fundação de Amparo à Pesquisa do Estado de São Paulo (Brazil), grant 98/15314-9.

\section{REFERENCES}

[1] Carissimi, A.S., Chaguri, L.C.A.G., Teixeira, M.A., Mori, C.M.C., Macchioni, M., Sant'Anna, E.T.G., Saldiva, P.H.N., Souza, N.L. and Merusse, J.L.B. (1999) Effects on intracage ammonia on ciliated epithelium of respiratory tract of rats maintained in two ventilated system for animal facilities with different frequency bedding changes. Brazilian Journal of Veterinary Research and Animal Science, 1, 99-118.

[2] Carissimi, A.S., Chaguri, L.C.A.G., Teixeira, M.A., Mori, C.M.C., Macchioni, M., Sant'Anna, E.T.G., Saldiva, P.H.N., Souza, N.L. and Merusse, J.L.B. (2000) Effects of two ventilation systems and bedding change frequency on cage environmental factors in rats (Rattus norvegicus). Animal Technology, 51,161-71.

[3] Chaguri, L.C.A.G., Souza, N.L., Teixeira, M.A., Carissimi, A.S. and Merusse, J.L.B. (2001) Evaluation of reproductive indices in rats (Rattus norvergicus) housed under an intracage ventilation system. Contemporary Topics in Laboratory Animal Science, 40, 25-30.

[4] Teixeira, M.A., Chaguri, L.G., Carissimi, A.S., Souza, N.L., Mori, C.M.C., Gomes, V.M.W., Poli Neto, A., Nonoyama, K. and Merusse. J.L.B. (2000) Hematological and biochemical profiles of rats kept under Microambi- ental environmental system. Brasilian Journal of Veterinary Research and Animal Science, 37, 341-347. doi:10.1590/S1413-95962000000500001

[5] Teixeira, M.A., Sinhorini, I.L., Souza, N.L. and Merusse, J.L.B. (1999) Microenvironmental ventilation system for laboratory animal facilities with air distribution by means of plennum chambers. Animal Technology, 50, 187-195.

[6] Teixeira, M.A., Souza, N.L. and Merusse, J.L.B. (2001) Mice productivity in a microenvironmental ventilation system using plennum chambers. Animal Technology, 52, 233-242.

[7] Merusse, J.L.B. (1995) Equipamento para criação e manutenção de animais utilizados em experimentação biomédica e respectivo processo de distribuição unidirecional do ar-PI9302341-3. Revista de Propriedade Industrial, 1262, 28-56.

[8] Canadian Council on Animal Care (1980) Guide to the care and use of experimental animals. National Academy Press, Ottawa, 15-22.

[9] Canadian Council on Animal Care (1984) Guide to the care and use of experimental animals. National Academy Press, Ottawa, 150-152.

[10] Companhia de Tecnologia de Saneamento Ambiental (1992) Ventilação industrial. CETESB, São Paulo.

[11] Macintyre, A.J. (1990) Ventilação industrial e controle da poluição. Guanabara, Rio de Janeiro.

[12] Mesquita, A.L.S., Guimarães, F.A. and Nefussi, N. (1988) Engenharia de ventilação industrial. CETESB, São Paulo.

[13] Ayadi, A., Ferrand, G., da Cruz, I.G. and Warot, X. (2011) Mouse breeding and colony management. Current Protocols in Mouse Biology, 239-264.

[14] Gamble, M.R. and Clough, G. (1976) Ammonia build-up in animal boxes and its effect on rat tracheal epithelium. Laboratory Animals, 10, 93-104. doi:10.1258/002367776781071477

[15] Perkins, S.E. and Lipman, N.S. (1996) Evaluation of microenvironmental conditions and noise generation in three individually ventilated rodent caging systems and static isolator cages. Contemporary Topics in Laboratory Animal Science, 35, 61-65.

[16] Serrano, L.J. (1971) Carbon dioxide and ammonia in mouse cages: Effect of cage covers, population and activity. Laboratory Animal Science, 21, 75-85.

[17] Shaw, B.H. (1976) Air movements within animal houses, Laboratory Animals, 7, 185-298.

[18] Chaguri, L.C.A.G. (1998) Ventilação microambiental para biotérios: Estudo experimental em ratos (Rattus norvegicus). Faculdade de Medicina Veterinária e Zootecnia da Universidade de São Paulo, São Paulo.

[19] Martinewski, A., Souza, N.L., Aranha, E.F.C. and Meru- 
sse, J.L.B. (2010) Controle termo-higrométrico microambiental para animais de laboratório por meio de tecnologia termoelétrica: Estudo experimental para roedores de laboratório. Brazilian Journal of Veterinary Research and Animal Science, 47, 315-322.

[20] Silverman, J., Bays, D.W., Copper, S.F. and Baker, S.P. (2008) Ammonia and carbon dioxide concentrations in disposable and reusable ventilated mouse cages. Journal of the American Association for Laboratory Animal Science, 47, 57-62.

[21] Riskowski, G.L., Harrison, P.C. and Memarzadeh, F. (2006) Mass generation rates of ammonia, moisture, and heat production in mouse cages with two bedding types, two mouse strains, and two room relative humidities. ASHRAE Transactions, 112, 134-144.

[22] Krohn, T.C. and Hansen, A.K. (2000) The effects and tolerances for carbon dioxide in relation to recent developments in laboratory animal housing. Scandinavian Journal of Laboratory Animal Science, 27, 173-181.

[23] Baumans, V., Schlingmann, F., Vonck, M. and Van Fith, H. (2002) Individually ventilated cages: Beneficial for mice and men? Contemporary Topics in Laboratory Animal Science, 41, 13-19.

[24] Martinewski, A., Correia, C.S.C., Souza, N.L. and Merusse, J.L.B. (2012) Mouse housing system using pressurized cages intraventilated by direct-current micro fans. Journal of the American Association for Laboratory Animal Science, 51, 177-180.

[25] Institute of Laboratory Animal Resources Commission on Life Sciences (1996) Guide for the care and use of laboratory animals. National Research Council, National Academy Press, Washington, DC. 